\title{
Developing Skills in Years 11 and 12 Secondary School Economics
}

\author{
Anthony Stokes ${ }^{1, *} \&$ Sarah Wright ${ }^{1}$ \\ ${ }^{1}$ School of Arts and Sciences, Australian Catholic University, Strathfield, Australia \\ *Corresponding author: School of Arts and Sciences, Australian Catholic University, 25A Barker Road Strathfield. \\ NSW, 2135, Australia Tel: 61-2-9701-4210Ｅ-mail: Tony.Stokes@acu.edu.au
}

Received: March 19, $2013 \quad$ Accepted: May 2, $2013 \quad$ Online Published: May 18, 2013

doi:10.5430/jct.v2n1p130 URL: http://dx.doi.org/10.5430/jct.v2n1p130

\begin{abstract}
This paper explores different approaches for developing skills in economics in schools. It considers the different preferred learning styles of students through the VARK method and applies a contextual learning approach to engage students and develop skills. The key skills that are considered are literacy, numeracy, information and communication technology, and critical and creative thinking. Graduate surveys and undergraduate student feedback are used to demonstrate the success of this approach, as it was applied at a university in Sydney, Australia.
\end{abstract}

Keywords: learning styles; economics; VARK; developing skills; student engagement

\section{Introduction}

As Australian schools move towards the introduction of a national curriculum in economics and business, this provides us with the opportunity to review the skills that are required in years 11 and 12 economics courses. The skills that will be considered in this paper are the ones put forward in the Australian Curriculum Assessment and Reporting Authority (ACARA) (2012) draft paper, Shape of the Australian Curriculum: Economics and Business. The main areas of skill development that will be considered by this paper on developing skills in economics are:

- Literacy

- Numeracy

- Information and communication technology (ICT)

- Critical and creative thinking

There are a number of factors that must be considered in attempting to develop skills in economics. These include the students' preferred learning styles and prior levels of knowledge, understanding and skill development.

\subsection{The Learning Styles of the Students}

Numerous studies (Fleming, 1995; Hill, 1997; Hedges, 2008; Stokes \& Wilson, 2009, Stokes \& Wright, 2012) demonstrate that students differ in their preferred learning styles. To satisfactorily develop skills in economics it is important to recognise this difference in student preferences for learning styles and to apply a variety of learning styles and opportunities for students to learn and develop skills. One method for measuring learning styles is VARK. VARK determines students preferred modes of intaking, processing and outputting information. This approach is called VARK because of its four modes of learning:

$V$ Preference for visual ways of representing information, for example video, graphic and symbolic ways

$A$ Preference for learning by aural methods, for example by listening and talking

$R$ Preference for reading and writing textual information

$K$ Preference for kinesthetic learning experiences and practices.

The learning styles of students differ with the individual but also differ with the disciplines that the students choose to study. Fleming (2013) reports that law students are more likely to have larger proportions of $R$, Read/write students and teachers than, say, nursing, where students are more likely to have K, Kinesthetic preferences. Graphic designers, performing arts and computer-systems students have a greater proportion of V, visual preferences. A study 
by Stokes and Wilson (2009) at the University of Wollongong of first year economics students showed that the students generally had a diverse range of preferred learning styles. Students were asked to respond to each of the thirteen questions by nominating any one or more of the above modes as appropriate for them. The average number of responses for each mode were 3.7 for $V, 3.5$ for $A, 5.0$ for $R$ and 4.0 for $K$. Whilst the Readlwrite preference was ranked the highest, the other modes were also significant, implying that Visual, Audio and Kinesthetic are important modes of processing information by economics students. A few examples show the variability of student preferences. For some, only one mode dominated. A student who had studied economics at the year 12 Higher School Certificate (HSC), who got 66 percent in the mid-session test economics test scored a V,A,R,K of 3,8,0,2. Another HSC student who got 60 percent scored 9,3,2,6 and an overseas student who got 84 percent scored 4,3,8,4.

There are also differences between males and females. Fleming (2013) states that the VARK survey results show that males have more Kinesthetic responses and females more Read/write responses. The majority of students, however, are likely to be multi-modal, i.e. they have more than one learning preference. It is even possible that they have an equal preference for all four learning styles. For this reason it is important to develop teaching strategies in economics that cater for all learning preferences and styles.

\subsection{Prior Learning and Contextual Learning}

Another important consideration in developing skills in economics is to create relevance for the students. This can generally be achieved by considering the students' prior learning backgrounds and creating a learning environment that is relevant to the students. The student who works at McDonalds would have some knowledge of customer service and selling products. This knowledge could be used in discussing demand and supply in a year 11 economics program. Similarly a student who goes shopping would have been involved in basic consumer choice and has knowledge of how price affects the quantity of products that they will purchase.

Similarly, the Kinesthetic learning preference refers to the 'perceptual preference related to the use of experience and practice (simulated or real).' The key is that people who prefer this mode are connected to reality, "either through concrete personal experiences, examples, practice or simulation" (Fleming \& Mills, 1992, pp. 140-141). It includes demonstrations, simulations, videos and movies of 'real' things, as well as case studies, practice and applications. It is possible to combine the Kinesthetic learning preference with other preferences in R, reading and writing about real world events, $\mathrm{V}$, watching videos on global events or environmental issues, and $\mathrm{A}$, discussing real word events or issues.

\section{The Methodology for Developing Skills in Economics}

\subsection{Developing Literacy Skills in Economics}

The ACARA draft paper, Shape of the Australian Curriculum: Economics and Business, states that

In the Economics and Business curriculum, students learn to critically examine a variety of sources, including print, online and other media to acquire economic and business information. They will learn to effectively use the specialised language and terminology of economics and business when interpreting and analysing and then communicating this information through a range of multimodal approaches, such as presentations, reports, written, spoken, visual, print, digital/online forums and to a range of audiences (ACARA, 2012, p. 18).

Economics makes considerable use of specialised language, terminology and concepts that differ from the general interpretation of those words in society (Gale, 2003). For this reason it is important to teach the students the skills to comprehend the meaning of economic terminology in the general application of words in a variety of sources including print, online and other media. Everyday words such as rent, capital and investment have different meanings in economics. It is important to demonstrate these differences in a contextual environment so that students can see the real world application of economic terminology. One example of how that can be achieved is by choosing a contemporary economic issue such as an environmental problem or a global economic event in an article or other form of media and ask the students to find examples of economics terms in that source. Activity 1 provides some examples of the types of concepts that can be found in many articles. 


\section{Activity 1: Economic Terms}

What examples are there in the article of the economic concepts of

- Scarcity

- Needs

- Opportunity cost

- External cost

- Government

- Trade

- Profit motive

- Markets

- Factors of production

- The global economy

The students would have to have some knowledge of the meaning of the economic terms and concepts, before they could relate that concept to the real world examples. The exercise would measure the students' skills at applying their economic understanding in the real world.

\subsection{Developing Numeracy Skills in Economics}

The ACARA shape paper states that

In the Economics and Business curriculum, students apply relevant numeracy knowledge and skills when creating and using charts, statistics, graphs and models that display economic and business data. They will use their numeracy knowledge and skills to display, analyse and interpret economic and business data, draw conclusions and make predictions and forecasts (ACARA, 2012, p. 18).

A study by the Australian Council of Education and Research (Thomson et al., 2005) found that effective teachers:

- have high expectations of all students and set challenging tasks and goals appropriate for each student

- integrate their content knowledge and their teaching skills to make connections that engage student interest and maintain involvement

- monitor student progress using their knowledge of each student's current achievement and the next steps appropriate for them, and provide feedback to the student

- enjoy mathematics and take pleasure in students' enjoyment and success.

The key elements emerging from studies examining effective numeracy teaching practices are a clear focus on concepts and thinking, an emphasis on valuing children's strategies, and encouraging children to share their strategies and solutions (Thomson et al., 2005).

The teaching of numeracy skills in economics is becoming more challenging as a higher proportion of students are not studying mathematics in years 11 and 12. The key to teaching numeracy skills in economics is creating relevance for the students to learn and apply these skills. Students will have different levels of prior knowledge and skill levels in numeracy. For this reason it is important that activities are structured so that they allow students to work at their own pace. Activity 2 provides an example of students learning and applying numeracy skills in year 11 economics.

It is important to have students involved in all stages of the activity. A student should draw the demand curve graph on a board. Ask the other students to give the student a score out of 10 for the activity. If students find errors in the answer provided, challenge them to discuss the errors and how to correct the errors on the graph. It is important to praise the students for their achievements. In time the students will become more aware of what is required for correctly drawing a graph in economics. They will aim to get the perfect 10 score as they draw the graphs. This is one advantage of teaching numeracy in economics, students can receive almost instant feedback and they can develop their skills to achieve a perfect 10 , which is an intrinsic reward. The goal for the students should always be the perfect score but it is important to encourage the other students, who are improving their skills, but have not achieved the perfect 10 . 


\section{Activity 2: Create your own business}

Assume that you are going to start up a business at your school (or at a local market on the weekend) selling a new product (good or service) to your fellow students. N.B. The teacher may like to do this as a group work activity where a small group of students decide on a product.

Firstly consider the factors that would influence the demand for particular products and select a product that you think might be successful. A business needs to know the quantity of a product that will be purchased by consumers at various price levels. One way a firm will initially try to measure this is by market research or a survey. Survey 10 20 of your fellow students as to whether they would buy this product and the quantity that they would buy at various price levels. Write these results in the demand schedule below.

\begin{tabular}{|l|l|}
\hline Price (per item) & Quantity demanded \\
\hline & \\
\hline & \\
\hline & \\
\hline & \\
\hline & \\
\hline
\end{tabular}

When you have completed your schedule, plot your results on a demand curve and answer the questions below. Remember to have a scale on each axis.

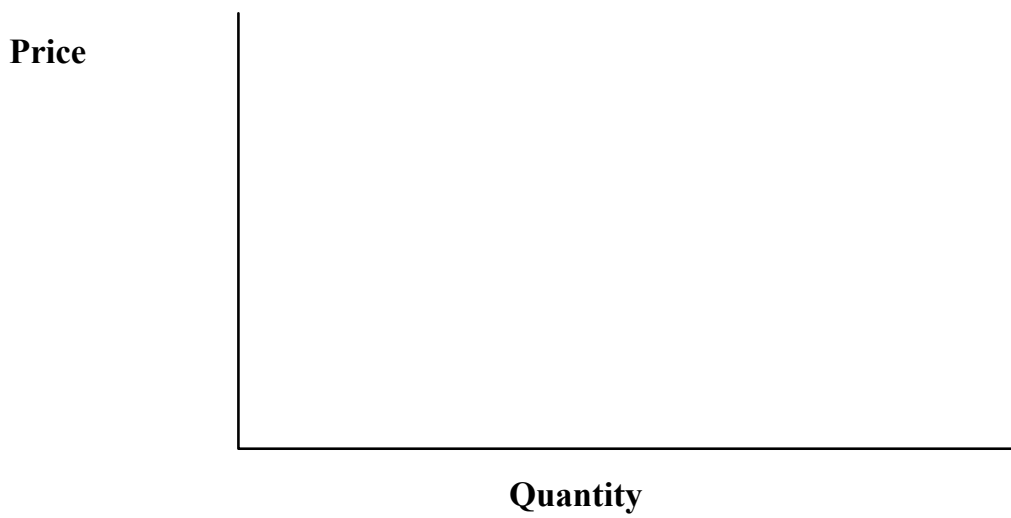

1. What do you notice about the shape of the demand curve?

2. How do changes in the price affect the quantity demanded?

3. Suggest 5 factors that could lead to an increase in demand for your product?

4. Plot a new hypothetical demand curve on your diagram, showing the effect of an increase in demand. What has happened to the quantity demanded at each price level?

Another activity that can integrate numeracy skills with real world application and content relates to Activity 3 on Australia's Balance of Payments. The activity considers the classifications in the Balance of Payments as well as using the current data in measuring the components of Australia's Balance of Payments. A good initial approach for teaching this skill, especially for the Visual learners is to set out a flow chart of the Balance of Payments as shown in Figure 1.

Activity 3: Measuring Australia's Balance of Payments

Consider the following data for the Australian Economy. All amounts are in billions of dollars. 


\begin{tabular}{lll}
\hline & $2010 / 11$ & $2011 / 12$ \\
\hline Goods credits & 247 & 265 \\
Goods debits & -219 & -250 \\
Service credits & 51 & 51 \\
Service debits & -58 & -60 \\
Net capital flows & 0 & -1 \\
Primary income & -52 & -46 \\
Secondary income & -2 & -1 \\
Net financial flows & $?$ & $?$ \\
\hline
\end{tabular}

Source: ABS, Balance of Payments, 5302.0

1. Into which categories would you put the following transactions:

(a) Indian students coming to Australia to study?

(b) Australian consumers buy BMW cars from Germany?

(c) A large Australian firm borrows money from overseas?

(d) An Australian resident sends money to a relative in Italy?

(e) Justin Bieber has his royalties from music sales in Australia paid to him in Canada?

(f) Toyota returns profits from its Australian car manufacturing business to Japan?

(g) Australians sending donations to people devastated by an earthquake in Asia?

(h) An Australian mining company sells iron ore to Japan?

(i) A migrant from China settles in Australia and brings in their financial assets?

2. What is the balance of goods and services for Australia in 2010-11 and 2011-12?

3. What is the approximate current account balance for Australia in 2010-11 and 2011-12?

4. Allowing for some rounding errors, what would be the overall balance of payments result in Australia in 2010-11 and 2011-12?

5. What is the balance of the financial account in Australia in 2010-11 and 2011-12?

6. What could be included in this category?

7. What are the main changes that have occurred in the balance of payment accounts for Australia between 2010-11 and 2011-12?

8. What are some possible implications of these changes for the economy? 


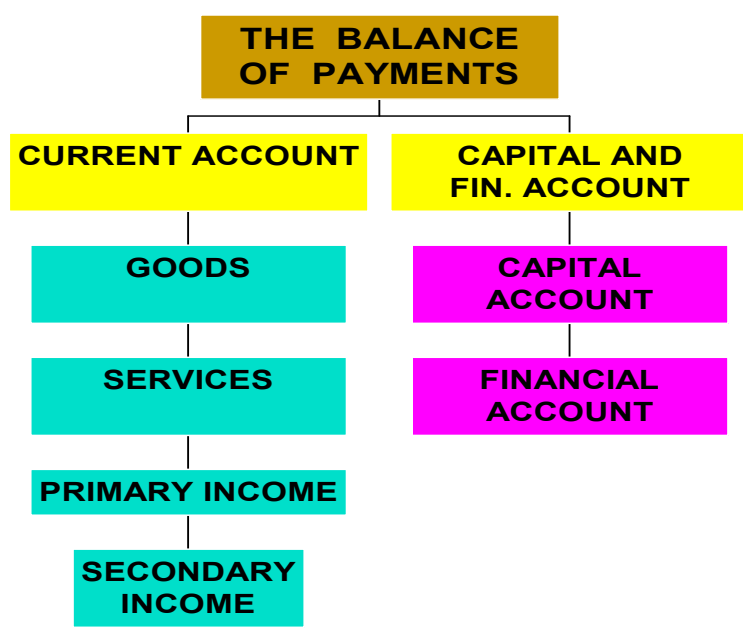

Figure 1: Australia's Balance of Payments

Another important skill in economics is graphical interpretation. The Reserve Bank of Australia and the Australian Bureau of Statistics (ABS) provide many useful and relevant graphs for interpretation and analysing trends in the Australian economy. In addition, the International Monetary Fund and the World Bank provide statistics and graphs on the global economy. Activity 4 is based on interpreting a graph from the Reserve Bank Chart Pack on unemployment rates and the participation rate. The activity also provides some data for calculating hypothetical unemployment and participation rates.

\section{Activity 4: Australia's Unemployment and Participation Rates}

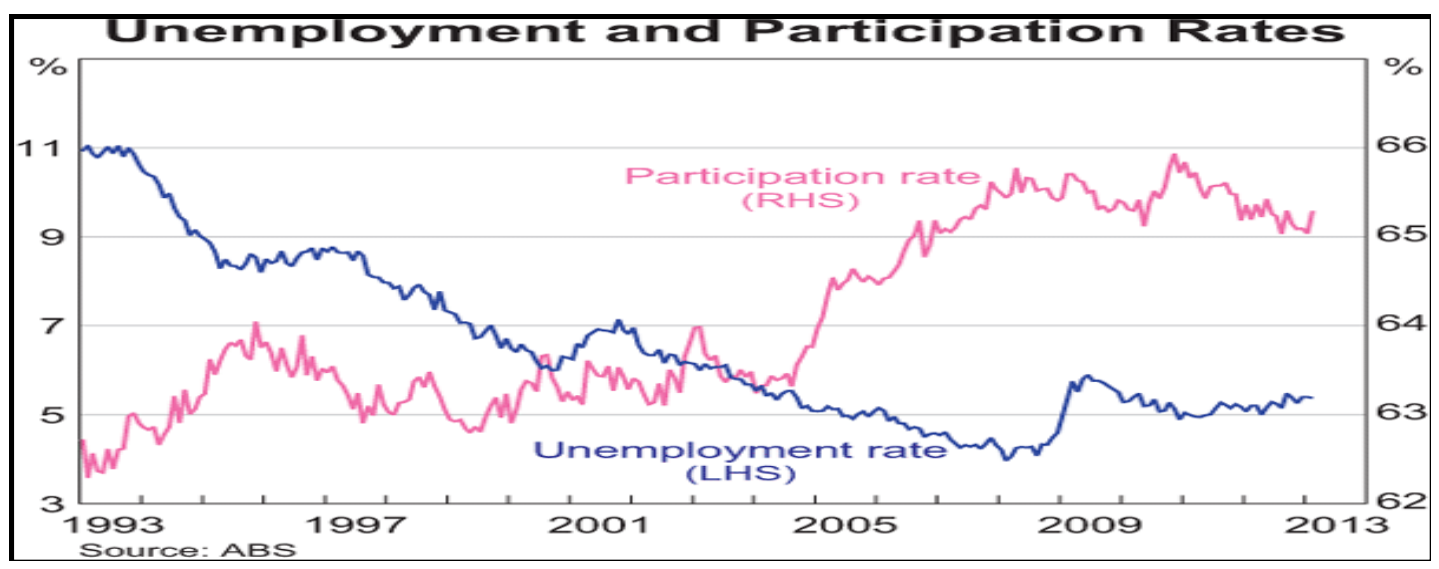

1. How is the level of unemployment measured by the ABS?

2. What was the level of unemployment in 1993 ?

3. What has been the trend in unemployment from 1995 to 2012 ? Can you suggest a reason for this?

4. How and why did this pattern change in 2008 ?

5. What does the 'participation rate' measure?

6. What was the level of the participation rate in 2012? What trend has been occurring in the participation rate in the period 2003-2012?

7. What impact does the participation rate have on the level of unemployment and vice versa? 
Consider the following table and answer the questions below. All figures are in millions.

\begin{tabular}{lcc}
\hline & Year 1 & Year 2 \\
\hline Unemployed & 10 & 11 \\
Employed & 90 & 95 \\
Working age population & 150 & 155 \\
\hline
\end{tabular}

8. What are the unemployment rates in years 1 and 2 ?

9. What are the participation rates in years 1 and 2 ?

2.3 Developing Information and Communication Technology (ICT) Skills

The ACARA Economics and Business Studies shape paper states that

In the Economics and Business curriculum, students develop the knowledge and skills to use ICT as an investigating tool to locate, research, access and display information, analyse and interpret data, and create, communicate and present economic and business information to a variety of audiences (ACARA, 2012, p. 19).

ICT skills allow students to find information that will be useful to them in their school life as well as their post-school life. Once the information is found it is important for the students to be able to interpret this information. Activity 5 shows how ICT skills can be developed by introducing economics students to the statistical data sources available on the ABS website.

\section{Activity 5: Using the internet to keep up to date with economic statistics from the ABS}

Use the Australian Bureau of Statistics website on the internet to answer the following questions:

1. What are the current levels of the following economic indicators in the Australian economy? Remember these should be expressed in annual terms.

- Inflation rate

- Unemployment rate

- Economic Growth rate

- The size of the Current Account Deficit

- The level of the Net Foreign Debt

2. How many major categories are there in the CPI? List them.

3. Which categories have contributed most to inflation in the last 12 months? What caused this?

4. Has there been deflation in any areas in the last quarter? Why did this occur?

\subsection{Developing Critical and Creative Thinking Skills}

The ACARA Economics and Business Studies shape paper states that

In the Economics and Business curriculum, students develop critical and creative thinking through an inquiry approach as they identify, explore and clarify issues, plan investigations, apply logical and inventive reasoning when interpreting and analysing data, and communicate complex decisions in relation to economics and business problems (ACARA, 2012, p. 19).

The best way to develop these skills in economics is to integrate the development of the skills throughout the course. As the student progresses through the course not only are the skills developed more deeply but they are also linked to the content that the students are studying. In Activity 2 question 4, the students were required to develop a hypothetical demand curve and to analyse what has happened to demand. In Activity 3, questions 7 and 8 , the students are required to interpret the Balance of Payments data for Australia and analyse the trends and draw conclusions of the possible implications of the trends for the Australian economy.

As students have different learning preferences, there are other creative and critical learning skills that can be developed in economics through the use of other visual means such as cartoons. Activity 6 provides one example of a contextual learning application that caters for the visual and more creative learners but also provides scope for discussion for the aural learners. 


\section{Activity 6: Using Cartoons in Economics}

Refer to the following cartoon. What economic issues is the cartoon expressing? Do you consider that the views of the cartoonist are correct?

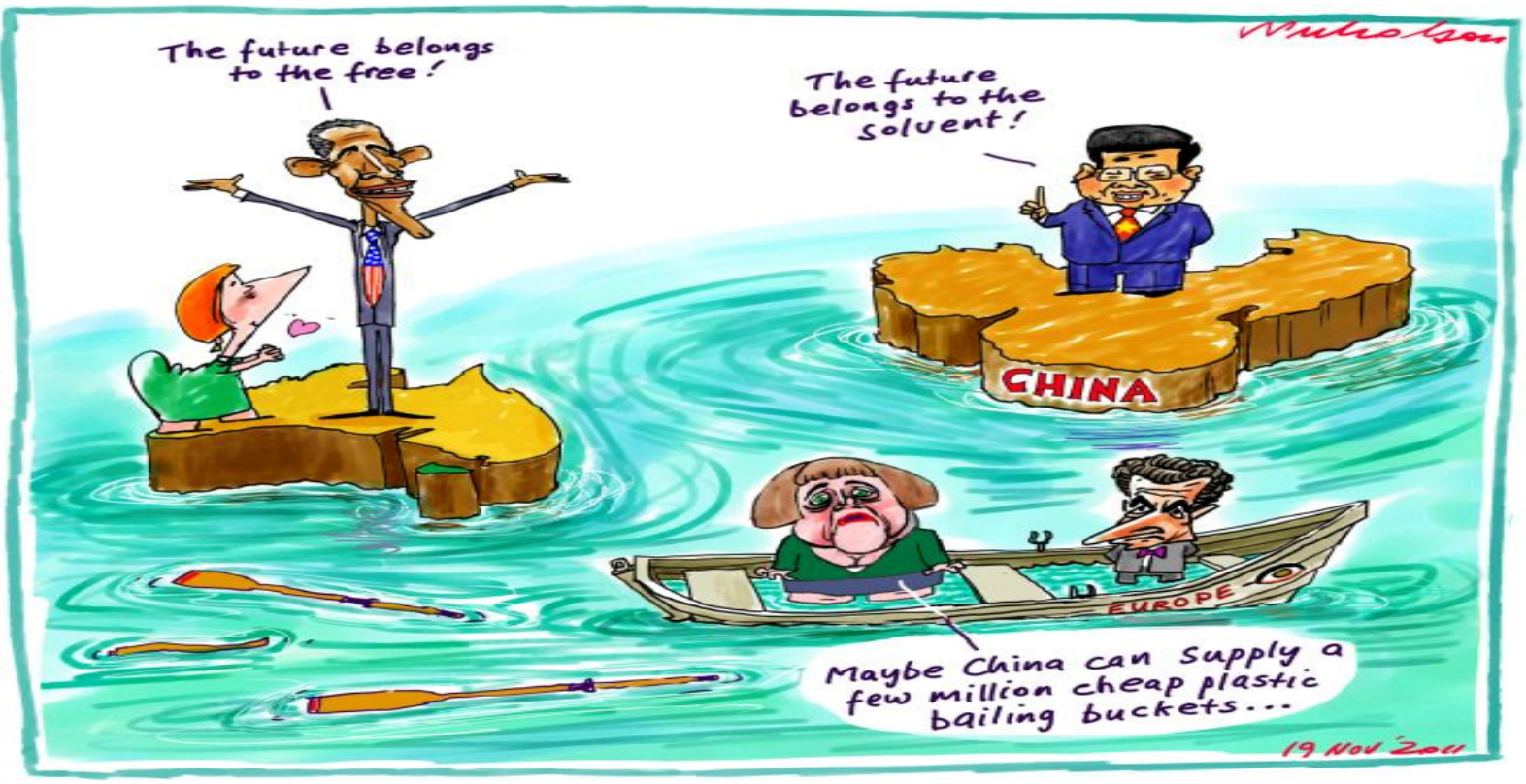

Cartoon by Nicholson from "The Australian" newspaper: www.nicholsoncartoons.com.au

Group work can also be a good way to develop oral communication skills, team work, critical and creative skills, amongst others. One ice breaker to introduce students to economics in year 11 is the activity 'stranded on a deserted island' (Activity 7). This allows the students to get to know each other and to think creatively and work together to find solutions to the basic economic problems. It is also a great tool for motivating students and creating an interest in economic problems and issues.

\section{Activity 7: Group Work - Stranded on a Deserted Island}

You are to break into groups of 4-5. You are to assume that you are stranded on a deserted tropical island, $500 \mathrm{kms}$ off the coast of Hawaii. You have the task of setting up an economic system on that island. You need to decide the basic economic questions of:

- What and how much to produce?

- How to produce it?

- Who will get it?

- What will be done to increase efficiency and economic growth?

It is important to develop a system that will sustain economic development. The role of each person in the group should be clearly explained. The group will have 20 minutes to plan their economic system and each group will give a 3-5 minute report.

\section{Evaluating this Learning and Teaching Approach}

There has been no formal measurement of such a teaching approach in an Australian school. This approach has, however, been used for a number of years in the economics classes at the Australian Catholic University (ACU), in Sydney, Australia. The economics major at ACU is designed to cater for a wide range of students with different abilities and aiming to pursue different careers. The Australian Tertiary Admission Ranks(Note 1) (ATAR) for economics students at ACU have ranged from less than 40 to 99 . Students studying economics at ACU do so through a variety of different degrees. These include: Bachelor of Arts, Bachelor of Arts and Economics, Bachelor of Arts (Psychology), Bachelor of Arts/Bachelor of Business or Commerce, Bachelor of Arts/Bachelor of Teaching, Bachelor of Arts/Bachelor of Social Work and Bachelor of Arts/Bachelor of Global Studies. These diverse factors 
are important in realising the need to cater for individual differences and aspirations and the challenge of catering for such a diverse student body.

The ACU teaching and learning approach will be evaluated both in terms of student satisfaction with the teaching and the development of generic skills in the economics program. The achievements that the Australian government consider desirable in terms of student satisfaction of teaching and generic skill development are measured through Course Experience Questionnaire (CEQ) data. The Australian government provides the CEQ data for all its universities on the 'my universities website'. The data from that website is used to evaluate the success of the teaching and learning approach at ACU compared to the other universities teaching economics in the state of New South Wales. Table 1 provides the average score achieved by ACU for economics in 2010 and 2011 compared to the average score for the nine universities with economics majors in New South Wales. In each of the years ACU was ranked first in the state for teaching quality and generic skills.

Table 1: Course Experience Questionnaire Data for Universities in New South Wales (2010-11 averages)

\begin{tabular}{lcccc}
\hline University & Teaching quality & $\begin{array}{l}\text { Ranking for } \\
\text { teaching quality }\end{array}$ & Generic skills & $\begin{array}{c}\text { Ranking for } \\
\text { generic skills }\end{array}$ \\
\hline $\begin{array}{l}\text { Australian Catholic } \\
\text { University }\end{array}$ & 90 & 1 & 97 & 1 \\
$\begin{array}{l}\text { Average for NSW } \\
\text { universities }\end{array}$ & 64 & & 84 & \\
Range of scores & $46-90$ & & $68-97$ & \\
\hline
\end{tabular}

Students also provided feedback in the form of unit and teaching evaluations of the economics units at ACU. Some examples of the common feedback provided by the students were that the lecturers:

- 'teach in a way that's relevant, interesting, modern, engaging, and easy to understand'

- 'use a variety of teaching strategies that keep a student interested during a lecture'

- 'provide weekly activities which give me a better understanding and provides examples which cater to different learning types'

- 'put effort in to communicate information in different ways to suit varying learning styles'

- 'use real world examples that I can relate to'

\section{Conclusion}

Students learn more effectively if they are interested in the subject matter that they are studying. One major advantage of teaching economics in years 11 and 12 in Australia is the contemporary nature of the course. It is important to relate the learning process to the prior learning and experiences of the students and to teach economics in a real world context.

This paper has explored the different learning preferences of students based on the VARK model and it has shown that it is important to consider these preferences in developing teaching and learning approaches. The ACARA shape paper for economics and business has set out the skills that students will be expected to develop in their studies. To most successfully develop these skills, it is important to develop activities that promote interest and relevance for the students and allows for students to progress at their own pace. These activities need to be both challenging and rewarding; rewarding in an intrinsic sense, in that the students gain satisfaction from the achievement of grasping and developing these skills. The evidence at Australian Catholic University suggests that the application of a teaching and learning approach that caters for different learning styles with an emphasise on contextual learning has been well received by students and enhances the students' experiences and achievements.

\section{References}

Australian Curriculum Assessment and Reporting Authority (ACARA). (2012). Shape of the Australian Curriculum: Economics and Business. Retrieved from http://www.acara.edu.au

Australian Government. (2013). MyUniversity. Retrieved from http://myuniversity.gov.au/ 
Fleming, N. (1995). 'I'm Different Not Dumb: Modes of Presentation (VARK) in the Tertiary Classroom', presented at the Annual Conference of the Higher Education Research and Development Society of Australasia, Rockhampton, July.

Fleming, N. (2013). VARK: A Guide to Learning Styles. Retrieved from http://www.vark-learn.com/english/index.asp

Fleming, N., \& Mills, C. (1992). Not Another Inventory, Rather a Catalyst for Reflection. To Improve the Academy, 11, 137-155.

Gale, J. (2003). The Language of Economics. Retrieved from SSRN: http://ssrn.com/abstract=468642

Hedges, M. (2008). Learning Styles and Introductory Economics: A Matter of Translation. Australasian Journal of Economics Education, 5(1), 1-16.

Nicholson, P. (2013). 'The Australian' newspaper. Retrieved from http://nicholsoncartoons.com.au/obama-temporarily-averts-fiscal-cliff-cartoon-2013-12-02.html

St Hill, R. (1997). 'Modal Preferences in Teaching and Learning Economics', Proceedings of the Fifth Annual Teaching Economics Conference, University of Southern Queensland, Toowoomba, 2-4 July, 53-79.

Stokes, A., \& Wilson, E. (2009). Catering for Individual Student Learning in Economics. American Journal of Business Education, 2(12), 41-48.

Stokes, A., \& Wright, S. (2012). More Effectively Engaging Students in University Economics Courses. Australasian Journal of Economics Education, 9(1), 1-20.

Thomson, S., Rowe, K., Underwood, C., \& Peck, R. (2005). Numeracy in the early years: Project Good Start: Final report, Australian Council for Educational Research, Camberwell, Australia: Victoria. Retrieved from http://www.acer.edu.au/research_projects/GoodStart.html

\section{Note}

Note 1 . The ATAR is the entry score required for university entry in Australia. It ranks student performance from 30.00 to 99.95 . 